\title{
ETNIS BETAWI: KAJIAN HISTORIS
}

\author{
BETAWI ETHNIC: HISTORICAL STUDY
}

\author{
Heru Erwantoro \\ Balai Pelestarian Nilai Budaya Bandung \\ Jln. Cinambo No. 136 Ujungberung - Bandung 42094 \\ e-mail: herubpnb@yahoo.com
}

Naskah Diterima:13 Januari 2014 Naskah Direvisi:11 Februari $2014 \quad$ Naskah Disetujui:18 Februari 2014

\begin{abstract}
Abstrak
Polemik tentang asal-usul etnik Betawi muncul ketika Lance Castles mengemukakan pendapat bahwa etnik Betawi baru muncul pada abad ke-20 dengan budak yang berasal dari etnik Bali sebagai unsur pembentuk yang dominannya. Berseberangan dengan Lance Castles, Ridwan Saidi mengatakan etnik Betawi tidaklah muncul secara tiba-tiba, tetapi sudah ada sejak zaman prasejarah yang dia sebut sebagai "Proto Betawi" dan terus berproses menjadi etnik Betawi di abad ke-17 Masehi. Berdasar dua pendapat itu, penelitian ini akan membahas sejarah etnik Betawi. Pertanyaan tentang siapa, kapan, dan bagaimana proses terbentuknya etnik Betawi menjadi fokus dari penelitian ini. Dengan memakai metode sejarah, ditelusuri berbagai pendapat para ahli yang telah melakukan penelaahan tentang etnik Betawi. Berbagai argumen dengan buktibukti yang kuat dari pendapat para ahli itu menegaskan bahwa etnik Betawi terbentuk dari suatu proses akulturasi yang berkesinambungan. Proses dari "Proto Betawi" menjadi "Betawi" berlangsung selama berabad-abad. Hanya saja, ada dua aspek yang perlu untuk diberi perhatian di dalam mengatasi polemik yang terjadi, yaitu: pertama, proses pembentukan etnik dan kedua, proses pemberian atau penyebutan nama suatu etnik/masyarakat. Proses terbentuknya masyarakat berlangsung lebih dulu sedangkan pemberian nama terjadi kemudian. Dengan demikian, tidaklah tepat bila pemberian nama suatu etnis dijadikan titik awal terbentuknya sebuah masyarakat.
\end{abstract}

Kata kunci: etnik, proto Betawi, Betawi, akulturasi.

\begin{abstract}
Polemic about the originality of Betawi ethnic appeared when Lance Castle stated that the birth of this ethnic beginning from the Balinesse slave (as dominant elements) in the 20th century. Different with Castlers, Ridwan Saidi says that Betawi ethnic was not suddenly appeared, but their existence since prehistorically era, called "Proto Betawi" and proceed become Betawi ethnic in 17th AD. According to the two theories, so this research will discuss about the history of Betawi ethnic. The questions of who, when, and how the process of Betawi ethnic appeared? is the main focus of this research. The research uses the historical method, and discussed about several theory from the experts. Kinds of argument with strong evidence from the experts claimed that Betawi appeared from the continuous process of acculturation. The process from "proto Betawi" to "Betawi" take place for centuries. But, there are two aspects that must be noticed to handle out the polemic, there is: the first is the ethnic figuration process, and the second is the process of giving ethnic/society name. The process of society figuration happened first, meanwhile the giving of the name of the society happened later.
\end{abstract}

Keywords: ethnic, proto Betawi, Betawi, acculturation. 


\section{A. PENDAHULUAN}

Sejak dahulu Kota Jakarta menjadi tempat pertemuan kelompok-kelompok etnis dari berbagai kawasan Nusantara yang ikut mewarnai dan memengaruhi pertumbuhan kota, baik pada zaman prakolonial, kolonial, maupun sesudahnya. Selain itu, Kota Jakarta pun memiliki arti penting bagi bangsa-bangsa asing yang pernah meninggalkan sejarah di tempat ini. Dengan demikian, Jakarta berkembang dari interaksi antarberbagai ragam kebudayaan etnis di kawasan Nusantara dengan hampir seluruh kebudayaan tinggi dunia, yaitu India, Cina, Islam, dan Eropa (Haris, 2007: 1).

Sudah menjadi pengetahuan umum bahwa etnis Betawi dikenal sebagai penduduk asli Kota Jakarta. Namun demikian, bila dibandingkan etnis Betawi di Jakarta dengan etnis lainnya di berbagai kota di Indonesia atau Pulau Jawa tentu sangat berbeda. Misalnya, di Jawa Barat, sebagai penduduk asli, etnis Sunda masih terlihat mendominasi. Begitu juga dengan etnis Jawa di Jawa Tengah dan Jawa Timur. Di Jakarta, sebagai penduduk asli, etnis Betawi tidaklah dominan baik dari segi jumlah maupun perannya.

Wilayah DKI Jakarta yang ditempati oleh etnis Betawi juga sangat kecil. Etnis Betawi bermukim secara tersebar di Jakarta, Bogor, Depok, Bekasi, Karawang, dan Tanggerang. Karena itulah kemudian muncul istilah Betawi Udik, Betawi Pinggir, dan Betawi Tengah.

Siapakah etnis Betawi sebenarnya? Menurut Shahab diperkirakan etnis Betawi baru terbentuk pada abad ke-19 sekitar tahun 1815-1893. Anggapan itu didasarkan pada studi sejarah demografi penduduk Jakarta yang dirilis oleh Lance Castle, sejarawan Australia. Dalam studi itu dinyatakan pada masa kolonial Belanda, pemerintah selalu melakukan sensus penduduk yang didasarkan pada bangsa atau golongan etnisnya. Dalam data sensus penduduk Batavia tahun 1615 dan 1815 tidak ada catatan mengenai golongan etnis Betawi. Adapun etnis Betawi muncul sebagai kategori baru dalam data sensus penduduk tahun 1930. Dalam sensus itu tercatat jumlah etnis Betawi sebanyak 778.953 jiwa dan menjadi mayoritas penduduk Batavia waktu itu (Castles, 2007: 24).

Selanjutnya, Parsudi Suparlan juga menyatakan bahwa kesadaran sebagai orang Betawi pada awal pembentukan kelompok etnis ini pun belum mengakar. Dalam pergaulan sehari-hari mereka lebih sering mengenalkan diri berdasar lokalitas tempat tinggal, seperti orang Kemayoran, orang Senen, atau orang Rawabelong. Pada sisi yang lain, pengakuan terhadap adanya orang Betawi sebagai sebuah kelompok etnis dan sebagai satuan sosial dan politik dalam lingkup yang lebih luas, yakni Hindia Belanda, baru muncul pada tahun 1923, saat Husni Thamrin, tokoh masyarakat Betawi mendirikan Perkoempoelan Kaoem Betawi. Baru pada waktu itu pula segenap orang Betawi sadar mereka merupakan sebuah golongan, yakni golongan orang Betawi (Castles, 2007: 16).

Namun demikian, tulisan Lance Castles "The Ethnic Profile of Jakarta" yang mengatakan bahwa etnis Betawi baru muncul pada abad ke-20 dan berasal dari budak yang dari Bali itu mendapat sanggahan keras dari Ridwan Saidi yang akhirnya menjadi polemik. Dari uraian di atas, diajukan masalah pokok penelitian "Siapakah Etnis Betawi itu?" Kemudian dari permasalahan pokok itu diajukan beberapa pertanyaan penelitian "Kapan munculnya etnis Betawi?" dan "Bagaimanakah sejarah terbentuknya etnis Betawi?" Dengan demikian, tujuan dari penelitian ini dimaksudkan untuk mempelajari serta sedapat mungkin menemukan akar permasalahan mengenai apa dan siapa etnis Betawi itu. Fokus penelitian ini ditekankan guna mencari jawaban atas permasalahan yang telah dirumuskan di atas. Untuk menjawab berbagai pertanyaan di atas, dalam penelitian ini digunakan metode sejarah. 


\section{B. METODE PENELITIAN}

Penelitian ini memakai metode sejarah yang meliputi empat tahap kerja, yaitu: heuristik, kritik, interpretasi, dan historiografi. Pada tahap heuristik pengumpulan data dilakukan melalui studi pustaka. Selanjutnya pada tahap kritik dilakukan kritik internal untuk memastikan keotentikan data dan kritik eksternal untuk memastikan validitas data. Setelah itu, pada tahap interpretasi data-data tersebut direkonstruksi berdasarkan aspek faktual (apa, siapa, di mana), aspek deskriptif (bilamana), dan aspek kausalitas (mengapa). Melengkapi tiga tahapan kerja itu kemudian dilakukan penulisan sejarah (historiografi).

\section{HASIL DAN BAHASAN}

Pada bagian ini deskripsi sejarah etnis Betawi akan ditelusuri melalui berbagai pendapat para ahli. Hal itu dilakukan sebab yang menjadi pokok permasalahan dalam penelitian ini terletak pada silang pendapat mengenai etnis Betawi antara Lance Castles dengan Ridwan Saidi. Tentu saja, pendapat para ahli yang lain penting dikemukakan meskipun yang bersilang pendapat hanya Lance Castles dengan Ridwan Saidi, itu dilakukan untuk menjaga netralitas dan juga mengisi sisi-sisi pandangan yang luput dari perhatian kedua ahli tersebut. Pendapat para ahli itu disajikan sebagaimana adanya kemudian interpretasi dari penulis disajikan di bagian penutup.

\section{Pendapat Lance Castles}

Pada tahun 1619, ketika Belanda merebut Kota Jayakarta dan mendirikan Kota Batavia sebagai pangkalan utama operasi mereka di Hindia Timur, daerah yang terletak di bagian tengah pantai utara Jawa Barat ini merupakan daerah yang jarang penduduknya dan diapit oleh dua kesultanan, yaitu Banten dan Cirebon. Dengan alasan keamanan, penguasa Kota Batavia tidak mendorong penduduk dari daerah pedalaman (yang mereka sebut dengan "orang-orang Jawa"- tanpa memerhatikan apakah mereka orang-orang Jawa Tengah, Jawa Timur, ataupun Sunda) untuk menetap di dalam dan di sekitar kota. Sebaliknya, selama dua abad populasi kota telah diisi dengan penduduk yang berasal dari wilayah-wilayah yang jauh dari Batavia.

Jan Pieterszoon Coen memulai kebijakan ini dengan mendorong orangorang Tionghoa selain juga orang-orang Banda yang telah ditaklukkan, untuk menetap di Batavia (de Haan, 1935: 371). Para penduduk bebas lainnya adalah orang-orang "Moor" (orang muslim dari India Selatan), Melayu, Bali, Bugis, dan Ambon. Meskipun demikian, jumlah penduduk di Batavia lama secara umum jumlahnya kalah besar jika dibandingkan dengan para budak. Pada awalnya, Belanda membawa para budak ini dari wilayah Asia Selatan, yaitu Pantai Coromandel, Malabar, Bengal, dan dari Arakan di Burma. Secara bertahap - terutama setelah Perusahaan Dagang Hindia Timur menyerahkan basisnya di Arakan (1665) Kepulauan Nusantara menjadi sumber utama yang menyediakan budak. Dalam perkembangan selanjutnya, Sumbawa, Sumba, Flores, Timor, Nias, Kalimantan, dan Pampanga di Luzon turut menyumbang bagi pasokan budak. Tetapi, sumber-sumber utama yang secara konsisten menjadi pemasok budak adalah Bali dan Sulawesi Selatan (de Haan, 1935: 349; Lekkerkerker, 1918: 409).

Karena rendahnya tingkat kesehatan di Batavia, terutama pada abad ke-18, penambahan secara tetap populasi penduduk dari luar wilayah Batavia perlu dilakukan secara terus-menerus. Pada seperempat abad terakhir abad ke-18 setiap tahun dilakukan impor 4.000 budak, dan pada masa Raffles hanya seperempat budak yang dilahirkan di sini (de Haan, 1935: 350). Hal itu menjelaskan mengapa beberapa kelompok masyarakat di Batavia menghilang dengan cepat jika imigran baru tidak berdatangan. Kehilangan ini pun dapat disebut sebagai hasil proses pencampuran ras dan budaya yang terjadi 
di masa Old Batavia. Proses "panci pelebur" ini didorong oleh perbedaan yang besar di dalam perbandingan jenis kelamin. Pada satu sisi, bangsa Eropa, Tionghoa dan mungkin sebagian besar imigran bebas yang datang dari daerah-daerah yang jauh adalah laki-laki. Sedangkan pada sisi lain, sebagian besar budak, terutama yang berasal dari Bali (walau jarang seluruhnya), adalah perempuan. Budakbudak dari anak benua India sebelum datang ke Batavia sudah memiliki identitas campuran dan menggunakan bahasa Portugis sebagai lingua franca. Mereka kadang-kadang disebut Toepassen (dari bahasa Hindustani dubashya, yang artinya penerjemah (Drewes dalam Schrieke, 1929: 139). Para budak yang dimerdekakan, yang sebagian besar menganut agama Kristen, disebut Mardijkers (berasal dari akar kata yang sama dengan bahasa Indonesia "Merdeka"). Mereka merupakan unsur penting dalam populasi Batavia pada abad ke-17 dan awal abad ke-18.

Gambaran komposisi etnis Batavia pada tiga periode, yaitu tahun 1673 (DaghRegister, 1674, Batavia: 1902: 27-30), tahun 1815 (Raffles, 1830: 270), dan Tahun 1893 (Encyclopaedie van Nederlandsch Indie, Den Haag/Leiden, n.d., Vol. I. hal.140). Pada akhir abad ke19, kelompok etnis Indonesia yang beraneka ragam, telah kehilangan indentitasnya. Mereka digantikan oleh sebuah suku bangsa baru, yaitu orang Batavia (Betawi atau Jakarta asli). Berdasarkan pernyataan Raffles bahwa sebagian besar budak yang ada pada tahun 1815 berasal dari Bali dan Sulawesi Selatan serta tidak ada yang berasal dari suku Jawa. Sangat jelas bahwa populasi Indonesia di kota ini pada waktu itu mayoritas berasal dari pulau-pulau di luar Jawa, dan terutama dari Indonesia Timur. Di Ommelanden (daerah pedalaman tepat di pinggir Batavia), populasi orang-orang Indonesia Timur persentasenya lebih kecil, tetapi secara keseluruhan jumlahnya tetap besar ( Lekkerkerker, 1918: 418). Karena itu, secara genetika orang-orang dari Indonesia Timur memiliki kontribusi terbesar bagi terbentuknya suku bangsa yang baru tersebut. Di pihak lain, kebudayaan yang turut membentuk suku bangsa tersebut, yaitu Islam dan bahasa Melayu, berasal dari (Indonesia) Barat.

Pada awalnya, terlihat sepertinya dialek Portugis para Mardijker akan dapat bertahan sebagai lingua franca penduduk Batavia, walaupun wilayah Indonesia Timur telah menggantikan peran daerah Asia Selatan sebagai sumber utama budak. Bahkan pada pertengahan abad ke-18, posisi bahasa Portugis yang digunakan para Mardijker masih sangat kuat sehingga instruksi resmi pemerintah kepada para wijkmeester (kepala kampung) dicetak menggunakan bahasa itu (de Haan, 1935: 407). Tetapi, sekitar awal abad ke-19 penggunaan dialek Portugis mulai menghilang dengan cepat, digantikan oleh rivalnya yang semakin kuat, yaitu "Omong Jakarta" atau bahasa Melayu Betawi. H.N. van der Tuuk percaya bahwa Bahasa Bali tingkat rendah merupakan dasar dialek Jakarta, tetapi Lekkerkerker (1918: 410413) yakin bahwa dialek Jakarta adalah bahasa Melayu dengan beberapa bentuk dan banyak kata-kata dari bahasa Bali, Jawa, Sunda, Arab, Tionghoa, dan Belanda. Hal yang sama juga berlaku pada agama Kristen yang pernah mendominasi pada masa-masa awal, yaitu ketika para Mardijker, Papanger (orang-orang yang berasal dari Pampanga di Luzon dan Mestizo (para penganut agama Kristen) merupakan bagian yang signifikan dari masyarakat Batavia. Pada periode selanjutnya, sebagian besar dari para budak maupun budak-budak yang telah dimerdekakan serta para pemukim bebas di Batavia adalah muslim. Atau jika mereka datang dari wilayah nonmuslim, seperti orang-orang Bali mereka akan segera beralih ke agama Islam (Lekkerkerker, 1918: 418-420). Orang Bali hampir tidak mungkin membawa agamanya maupun struktur sosialnya ke lingkungan barunya. Karena orang-orang Bali ini datang 
sebagai budak, mereka dipaksa untuk meninggalkan sebagian besar kebudayaan mereka. Hanya sebagian kecil orang Bali yang terpengaruh oleh usaha-usaha Belanda yang tidak terlalu serius untuk mengkristenkan mereka. Mereka itu terutama adalah para budak yang bekerja di tanah partikelir milik Cornelis Chastelein di Depok, suatu daerah yang terletak di bagian selatan perbatasan Kota Jakarta. Sampai saat ini, keturunan mereka tetap mempertahankan indentitas mereka yang berbeda (Lekkerkerker, 1918: 419420).

Orang-orang Mardijker pada akhir abad ke-18 dikenal sebagai "Kristen Pribumi" atau "orang Portugis" (yang menarik mereka adalah orang India dan bukan penduduk asli Indonesia, meskipun menggunakan nama dan bahasa Portugis sedikit di antara mereka yang merupakan keturunan Portugis). Beberapa di antara mereka kemungkinan terserap ke dalam golongan Indo-Eropa, sedangkan sebagian lainnya menjadi Muslim dan masuk ke dalam populasi Betawi. Sekelompok kecil komunitas Kristen di Tugu Selatan Tanjung Priok, menurut laporan sensus tahun 1930, terdiri atas keturunan para Mardijker (Departemen van Economicsche Zaken, 1935: 18.) Sedangkan orang-orang Papanger secara bertahap menjadi muslim, sehingga menghilangkan indentitas mereka sebagai kelompok tersendiri.

Orang-orang bebas di Batavia yang berasal dari berbagai macam kelompok etnis pada umumnya bertempat tinggal di kampung-kampung (wijken) yang disediakan untuk mereka. Mereka hidup di bawah perlindungan kepala kampung, yang disebut Mayor, Kapten, dan sebagainya. Beberapa peristiwa seperti penunjukan seorang Jawa untuk mengepalai Kampung Bugis pada akhir abad ke-18 dan reorganisasi milisi berdasarkan wilayah dan bukan kelompok etnis pada tahun 1828 mencerminkan semakin melunturnya indentitas suku bangsa di Batavia.
Sebuah laporan Batavia dari tahun 1799 masih menjelaskan perbedaan pekerjaan, pakaian, dan karakteristik orang-orang Melayu, Jawa, Bali, Mardijker, Bugis, dan Makasar. Tetapi seperempat abad kemudian, C.S.W. van Hogendorp hanya menyebutkan "orangorang Makasar, Bali, dan India (berasal dari pulau-pulau lain di kepulauan ini, dan secara umum disebut Melayu). Mereka begitu melebur dengan orang-orang Jawa sehingga mereka telah banyak mengadopsi adat istiadat dan kebiasaan-kebiasaan Orang Jawa".

Pada pertengahan abad ke-19 Van der Aa mencatat bahwa meskipun ada berbagai kelompok populasi, namun mereka "telah kehilangan sebagian besar karakter asli pendahulu mereka, dan tampaknya melalui perdagangan serta pernikahan campuran telah melebur menjadi suatu masyarakat. Dan sejak sekitar masa itu mereka dianggap sebagai suatu kelompok tersendiri. Pada tahun 1923, Mohammad Hoesni Thamrin mendirikan Kaoem Betawi sebagai sebuah organisasi kesukuan (sebagaimana Pasundan, Serikat Ambon, Persatuan Minahasa dan sebagainya), berdasarkan kepada populasi penduduk Jakarta asli”.

\section{Pendapat Ridw an Saidi}

Kapak batu adalah alat produksi manusia zaman lampau yang serba guna, sebelum mereka membuat pacul untuk bertani. Hasil ekskavasi di Jakarta tahun 1970-an, kapak batu hampir merata ditemukan diseluruh Jakarta, yaitu di Cengkareng, Sunter (Sontar), Cilincing, Kebon Sirih, Tanah Abang, Rawa Belong, Sukabumi, Kebon Nanas, Jatinegara, Cawang, Cililitan, Kramat Jati, Condet, Pasar Minggu, Pondok Gede, Tanjung (Timur), Lenteng Agung, Klapa Dua, Cipete, Pasar Jumahat, Karang Tengah, Ciputat (Tanggerang), Pondok Jengkol (Tanggerang), Pondok Cabe (Tanggerang), Cipayung (Tangerang), Serpong (Tangerang). Penemuan kapak batu itu membuktikan sejak 3.000 sampai 4.000 
tahun lalu tingkat penyebaran penduduk di Kalapa begitu merata. Inilah manusia proto Betawi (Saidi, 2002: 13).

Menurut Tony Djubianto mengacu pada geografi zaman es di mana Sumatera, Kalimantan, dan Jawa menyatu kemudian pecah tiga. Arus migrasi manusia di zaman ini bergerak dari barat ke timur, maka dari itu kiranya dapat disimpulkan bahwa manusia proto Betawi adalah migran yang datang dari barat. Setelah geografi zaman es, manusia Phitecantropus Erectus adalah manusia Nusa Jawa, yang mendirikan peradaban di kepulauan Jawa, termasuk Nusa Kalapa. Karena itulah bahasa yang dipergunakan oleh manusia Nusa Jawa, termasuk yang berdiam di Kalapa, adalah bahasa Kawi. Juga terdapat kesamaan alatalat produksi yang mereka pergunakan di zaman neolithicum. Konsep etnik belum muncul sampai dengan berakhirnya periode neolithicum (Saidi, 2002: 14).

Proses pembentukan entitas etnik di Nusa Jawa muncul pada abad ke-7. Di Nusa Jawa sebelah barat (kulon) terdapat Sunda dan Galuh, di Nusa Jawa sebelah tengah terdapat Kalingga, dan di Nusa Jawa sebelah timur (wetan) terdapat Kediri. Kebudayaan Nusa Jawa mulai memperlihatkan ciri lokal masing-masing dengan berdirinya pusat-pusat kekuasaan itu (Saidi, 2002: 33).

Sementara itu baik Kerajaan Sunda maupun Galuh tidak mempunyai angkatan laut yang baik sehingga kawasan pesisir kedua kerajaan itu dikendalikan Sriwijaya dan Kediri. Persaingan wong Melayu (Sriwijaya) dan wong wetan (Kediri) dalam penguasaan laut menyebabkan keterlibatan Cina. Perniagaan Cina terganggu akibat perang di lautan antara Sriwijaya dan Kediri. Usaha diplomasi Cina berhasil dengan membujuk kedua kerajaan itu bermusyawarah. Akhirnya, kendali lautan dibagi dua, sebelah barat sampai dengan Cimanuk dikendalikan Sriwijaya, sebelah timur mulai dikendalikan Kediri. Pelabuhan Kalapa termasuk dalam kendali Sriwijaya (Saidi, 2002: 33).
Penguasaan Sriwijaya atas laut tidak disertai dengan operasi teritorial. Maka Sriwijaya memberi tugas kepada mitranya Syailendra di Jawa Tengah untuk penguasaan wilayah teritorial. Namun kontrol Syailendra atas wilayah Jawa sebelah barat tidaklah efektif. Menyadari akan hal itu maka Sriwijaya mendatangkan migran suku Melayu dari Kalimantan bagian Barat ke Kalapa. Migrasi besarbesaran ini terjadi di antara kurun waktu abad ke-8 sampai abad ke-10. Pada periode inilah, mengacu pada teori Prof. Bern Nothofer dari Frankfurt University, terjadi secara meluas penyebaran bahasa Melayu. Yang pada gilirannya bahasa tersebut menjadi lingua franca di Kalapa menggeser kedudukan bahasa Sunda (Kawi) (Saidi, 2002: 34).

Jika berpegang pada pandangan Nothofer berkenaan dengan rute penyebaran bahasa Melayu (Polinesia Barat) dengan Kalimantan Barat sebagai titik sebarnya maka perjalanan penyebaran itu dimulai dari Kalimantan ke Laut Cina Selatan terus ke Bangka "Sumatera Tenggara" (Prabumulih-Lahat-Palembang) kemudian ke Kalapa. Di Kalapa orangorang Melayu itu membuat pemukiman di wilayah pesisir. Dari toponim di wilayah pesisir didapatkan nama tempat antara lain Tanah Melayu, Sunter, Kampung Melayu, dan Teluk Naga di Tanggerang (Saidi, 2002: 34).

Di Nusa Kalapa penyebaran bahasa Melayu dimulai dari pesisir. Maka lewat jalan perdagangan, juga jalan perkawinan, bahasa Melayu menyebar ke pedalaman. Di wilayah Kalapa, bahasa Sunda Kawi tetap bertahan sebagai bahasa kesusastraan dan bahasa komunikasi golongan penguasa. Namun, dalam perkembangan selanjutnya, proses pembentukan entitas kesukuan mengkristal. Masyarakat di Jawa Barat dari segi bahasa terbagi dua, yaitu mereka yang tetap berbahasa Sunda (Kawi) dan mereka yang menggunakan bahasa Melayu dan meninggalkan bahasa Sunda (Kawi). Agama Hindu menjadi agama resmi di kerajaan-kerajaan di Jawa 
sebelah Barat, sedangkan di Jawa Tengah dan Timur, agama Budha menjadi agama resmi (Saidi, 2002: 35).

Kapan sesungguhnya nama Betawi dipergunakan sebagai nama suku bangsa, tentunya setelah J.P. Coen menaklukkan Kraton Jayakarta (1619) dan memberi nama kota ini Batavia. Secara tertulis sebutan orang Betawi pertama kali terdapat dalam dokumen 1644 berupa testamen Nyai Inqua, janda Tuan Tanah Souw Beng Kong, Kapiten Tionghoa pertama di Batavia. Nyai Iqua menyebut seorang pembantu perempuannya adalah orang Betawi (Saidi, 2002: 95).

Dalam kitab Sejarah Banten disebutkan istilah wong Jakerta. Gubernur Jenderal VOC J.P. Coen sendiri pernah mempergunakan nama Jacerta, sebelum ia menetapkan nama Batavia. Jika nama wong Jakerta atau orang Betawi, baru dikenal pada abad ke-17, apakah sebelum itu tidak ada komunitas penduduk yang kemudian disebut suku bangsa Betawi? Apakah Nusa Kalapa tidak berpenduduk ketika Faletehan datang pada tahun 1526, dan menyusul kemudian J.P. Coen pada tahun 1619. Tentu saja tidak demikian. karena terdapat banyak nama suatu suku bangsa justru berasal dari orang asing, misalnya Indian di Amerika dan Aborigin di Australia. Tentu suku bangsa yang disebut Indian itu sudah ada jauh sebelum kedatangan Columbus (abad ke-15), begitu juga suku bangsa Aborigin pastilah sudah ada sebelum James Cook datang di Australia pada abad ke-18 (Saidi, 2002: 95-96). Tetapi apakah nama suku bangsa di kawasan yang disebut Nusa Kalapa, dan sudah berkelompok paling sedikit sejak 3000 tahun yang lalu itu? Jawabannya, suku bangsa itu belum ada namanya (Saidi, 2002: 97).

Di dalam naskah lama "nama suku bangsa" biasanya dikaitkan dengan nama kota/pulau dari mana nama orang tersebut berasal. Kita jumpai istilah orang Sulawesi, di samping orang Bugis dan orang Makasar. Kita jumpai juga istilah orang Sumatera, di samping orang Melayu, orang Batak, orang Palembang. Lalu kita juga dapatkan istilah "Orang Melayu Jawa", apakah yang dimaksud adalah orang yang bermukim di Nusa Jawa (Kalapa) yang berbahasa Melayu, atau orang dari suku bangsa Melayu (Sumatera Timur, Riau, Jambi, Kalimantan Barat) yang tinggal di Nusa Jawa (Kalapa). Dalam kasus ini tampaknya yang benar bahwa sebutan "orang Melayu Jawa" itu untuk komunitas penduduk di Jawa (Nusa Kalapa) yang berbahasa Melayu, dan kelompok suku bangsa ini kemudian hari disebut sebagai orang Betawi. Jadi, sebelum munculnya sebutan orang Betawi, dikenal beberapa sebutan untuk suku bangsa yang kemudian dikenal sebagai orang Betawi. Mereka disebut orang Jawa, orang Melayu Jawa, atau orang Jaketra. Sebutan lainnya mengacu pada agama yang dianutnya, di mana mereka dulu disebut sebagai orang Selam. Selanjutnya, tampaknya sulit untuk mengetahui sebutan lain di luar yang sudah diuraikan ini (Saidi, 2002: 97).

\section{Pendapat M. J unus M elalatoa}

Betawi adalah suku bangsa yang berdiam di wilayah DKI Jakarta, dan wilayah sekitarnya yang termasuk wilayah Provinsi Jawa Barat. Suku bangsa ini biasa pula disebut "Orang Betawi", "Melayu Betawi", atau "Orang Jakarta" (atau Jakarte menurut logat setempat). Nama Betawi itu berasal dari kata Batavia nama yang diberikan oleh Belanda pada zaman penjajahan dulu. Etnik Betawi memiliki latar belakang sejarah yang telah melewati rentang waktu yang cukup panjang. Sejak lebih dari 400 tahun yang lalu, masyarakat Betawi yang kemudian menjadi masyarakat seperti yang dikenal sekarang merupakan hasil dari suatu proses asimilasi. Masyarakat itu dengan budayanya merupakan hasil pembauran berbagai unsur budaya berbagai bangsa, dan suku bangsa yang berasal dari berbagai daerah di Indonesia (Melalatoa, 1995: 160). 
Jakarta sebagai suatu tempat yang terletak di pinggir pantai, dalam proses perjalanan sejarahnya, menjadi kota pelabuhan dan dagang. Kota ini kemudian menjadi pusat kota administrasi, politik, dan bahkan menjadi salah satu pusat untuk memperoleh pendidikan di Indonesia. Sifat dan ciri Kota Jakarta yang demikian itu telah memungkinkan menjadi arena tempat pembauran berbagai etnik yang ada di Indonesia, dan bahkan berbagai bangsa yang berasal dari berbagai penjuru dunia. Mereka datang dengan berbagai macam kepentingan, dan juga dengan latar belakang kebudayaan yang berbeda pula. Pembauran itu telah melahirkan suatu masyarakat dan kebudayaan baru bagi penghuni Kota Jakarta tadi, yang kemudian dikenal sebagai "Orang Betawi" (Melalatoa, 1995: 160).

Bangsa-bangsa dan suku-suku bangsa yang berbaur dan yang kemudian mewujudkan kebudayaan baru tadi dalam periode waktu yang berbeda-beda. Pihakpihak yang datang itu antara lain ialah orang Portugis, Cina, Belanda, Arab, India, Inggris, Jerman; dan dari daerah-daerah di Indonesia, misalnya Jawa, Melayu, Bali, Bugis, Sunda, Banda, dan lain-lain. Pada periode yang lebih akhir variasi suku bangsa yang datang menjadi lebih banyak lagi. Kemudian diketahui bahwa berbagai unsur budaya terpadu menjadi satu budaya yang disebut kebudayaan Betawi tadi. Perpaduan itu tercermin dalam bahasa, kepercayaan, kesenian, teknologi, seperti pakaian, makanan, dan lain-lain. Sebagai contoh, kebudayaan Betawi diselipi unsur budaya Portugis terutama dalam hal bahasa. Sampai dengan abad ke-18 bahasa Portugis pernah menjadi bahasa pergaulan (lingua franca) di kalangan masyarakat yang tinggal di Jakarta tadi. Pengaruh Portugis ini terasa pula dalam seni musik, yang kemudian dikenal menjadi musik keroncong, juga tari-tarian, pakaian warna hitam, dan lain-lain. Kebudayaan Portugis ini masuk melalui orang Mardijkers, yaitu orang yang semula berasal dari Malabar,
India, yang telah menyerap budaya Portugis (Melalatoa, 1995: 160).

Demikian pula kebudayaan Cina telah banyak pula memberikan pengaruhnya di kalangan penduduk Jakarta. Orang-orang Cina yang datang ke Jakarta sebenarnya berasal dari etnik yang berbeda di daerah asalnya di daratan Cina. Masing-masing etnik itu menggunakan bahasa tersendiri, yaitu bahasa Hokkien, Teo-Chiu, Hakka, dan Katon. Di Jakarta, unsur budaya Cina yang terserap ke dalam budaya Betawi adalah unsur bahasa, kesenian, dan makanan. Pengaruh kesenian Cina tercermin dalam irama-irama lagu, alat-alat musik, bahkan nama-nama keseniannya sendiri (Melalatoa, 1995: 161).

Kesenian memang merupakan salah satu unsur budaya yang pada hakikatnya lebih mudah dinikmati dan diterima oleh pihak-pihak yang berlatar budaya berbeda. Penikmatan keindahan itu tidak terhalang oleh batas suku bangsa atau bangsa. Rupanya hal inilah yang menyebabkan tidak terhalang masuknya kesenian Cina, seperti gambang rancag, atau rebana sebagai unsur budaya Arab, atau topeng dari unsur budaya Sunda, dan lain-lain. Pengaruh kebudayaan Arab masuk melalui orang Moors (berasal dari kata Mouro, yaitu istilah Portugis untuk orang Muslim). Pengaruh Arab ini sudah berlangsung sejak abad ke-19, dan pengaruh itu tampak dalam bahasa, kesenian, dan lain-lain. Pengaruh lain berasal dari Belanda, misalnya dalam sistem mata pencaharian, pendidikan. Budaya asing lain yang tidak begitu banyak meninggalkan bekas adalah Jerman, Inggris, Perancis, India (Melalatoa, 1995: 161).

Adapun tanda-tanda kehadiran berbagai suku bangsa di Jakarta dapat diketahui dari nama-nama tempat yang sama dengan nama suku bangsa tertentu. Sampai sekarang dikenal adanya namanama wilayah di Jakarta, seperti Kampung Melayu, Kampung Bali, Kampung Bugis, Kampung Makasar, Kampung Jawa, Kampung Ambon. Nama-nama tersebut 
memberi petunjuk bahwa pada masa lampau anggota suku bangsa tertentu itu hidup mengelompok. Orang Bali dan Bugis diketahui sebagai unsur pendatang yang sudah hadir sejak beberapa abad yang lalu. Orang Jawa pun telah datang sejak beberapa abad yang lampau sebagai pekerja-pekerja di sekitar Jakarta. Sebaliknya orang Sunda, yang daerah asalnya lebih dekat letaknya, baru datang di Jakarta sekitar abad ke-19. Pada mulanya mereka berdiam di sekitar Jatinegara (Melalatoa, 1995: 160).

Kelompok orang Banda dan Maluku dibuang oleh Belanda ke Batavia tahun 1621. Di sini antara orang Banda dengan penduduk setempat terjadi pergaulan yang erat dan kawin mawin. Ketika Belanda memerintahkan kembali ke Banda mereka memilih tetap tinggal di Jakarta yang dahulu dikenal dengan Sunda Kalapa itu. Mereka umumnya berada di sekitar pasar ikan sekarang, tetapi tidak meninggalkan bekas misalnya dengan nama "Kampung Banda", karena mereka cepat membaur dengan penduduk setempat tadi. Menurut Frans Hitipeuw dalam Makalahnya "Unsur-unsur Kebudayaan Banda dalam Kebudayaan Betawi” (1985) banyak persamaan atau pengaruh budaya Banda pada budaya Betawi, misalnya corak perahu, alat penangkap ikan, jenis makanan seperti onde-onde, waji, dan lainlain, permainan beklen dari kulit siput, congklak (Melalatoa, 1995: 161).

Selanjutnya, di antara kelompokkelompok etnik tersebut di atas, keberadaan orang Melayu menempati kedudukan yang cukup penting, meskipun jumlahnya relatif lebih kecil dibandingkan dengan orang Bali, Bugis, Cina, dan lainlainnya. Kedudukan orang Melayu ini menjadi lebih penting karena peran bahasanya, bahasa Melayu yang digunakan sebagai bahasa pergaulan (linggua franca). Jakarta sebagai kota pelabuhan, kota dengan berbagai latar budaya dan bahasa yang berbeda tentu memerlukan bahasa pergaulan. Bahasa Melayu memang telah menjadi lingua franca di berbagai kota pelabuhan atau kota-kota pantai lainnya di Nusantara ini sejak lama. Kedudukan bahasa Melayu yang demikian di Jakarta menyebabkan kosa katanya diperkaya unsur kosa kata dari bahasa lain yang ada di Jakarta waktu itu. Kosa kata yang turut memperkaya bahasa Melayu itu berasal dari bahasa-bahasa Portugis, Cina, Arab, Belanda, Bali, Jawa, Sunda, dan dari bahasa etnik lainnya. Campuran dari beberapa bahasa yang berintikan bahasa Melayu itulah rupanya yang telah melahirkan Bahasa Betawi atau Omong Betawi, yang kadang-kadang juga disebut Omong Jakarta (Melalatoa, 1995: 161).

\section{Pendapat Bondan Kanumoyoso}

Hingga saat ini penulisan sejarah (historiografi) tentang Jakarta/Batavia telah mengalami perkembangan yang cukup pesat. Berbagai karya ilmiah ditulis oleh para sejarawan untuk mengulas bermacam aspek yang berkaitan dengan sejarah Kota Jakarta. Di antara berbagai karya ilmiah tersebut artikel Lance Castles yang berjudul "The Ethnic of Jakarta" yang terbit pada tahun 1967 menempati posisi istimewa. Artikel ini seringkali menjadi sasaran kritik dari masyarakat Betawi. Mereka melancarkan kritik terhadap argumen Castles yang menyatakan bahwa salah satu unsur utama yang membentuk etnis Betawi adalah para budak. Sebenarnya artikel Castles tidak hanya membahas masalah asal-usul orang Betawi. Sesuai dengan judulnya, karya Castles membahas karakteristik penduduk Jakarta tahun 1960-an yang bersifat multietnis (Bondan, 2007: xi-xii).

Castles bukanlah orang pertama dan satu-satunya yang mengajukan teori pembentukan etnis Betawi yang dihubungkan dengan unsur budak. Dalam berbagai karya sejarah tentang masyarakat Kota Jakarta kemunculan orang Betawi seringkali disinggung walaupun secara sekilas. Persamaan penting di antara karyakarya sejarah Kota Jakarta ialah mereka menyebutkan bahwa orang Betawi berasal dari pencampuran berbagai macam etnis 
yang menghuni Kota Batavia pada abad ke-17 dan 18 (lihat Pauline Dublin Milone, 1966; Jean Gelman Taylor, 1983, dan Susan Abeyasekere, 1987). Sampai dengan tahun 1980-an belum ada keberatan yang diutarakan oleh orang Betawi terhadap teori pembentukan etnis Betawi tersebut. Reaksi penolakan secara keras dari masyarakat Betawi baru muncul sekitar tahun 1990-an (Shahab, 1994: 82). Mereka yang menolak beranggapan bahwa orang Betawi telah ada bahkan sebelum Kota Jakarta didirikan (Bondan, 2007: xii).

Sejarah orang Betawi terkait erat dengan sejarah Kota Jakarta yang di masa kolonial disebut dengan Batavia. Orang Betawi adalah penduduk asli Jakarta. Mereka diduga merupakan salah satu suku yang paling akhir terbentuk di antara sukusuku pribumi lainnya yang ada di Indonesia. Castles sampai pada argumen bahwa para budak adalah unsur utama yang membentuk etnis Betawi karena ia mendasarkan analisisnya pada data jumlah budak yang menetap di Kota Jakarta. Memang benar bahwa sampai dengan abad ke-18 jumlah budak di dalam Kota Batavia lebih banyak daripada jumlah penduduk bebas. Namun jika kita mengalihkan perhatian ke wilayah di luar tembok kota yang disebut dengan Ommelanden akan didapat gambaran yang berbeda. Jumlah penduduk Ommelanden jauh lebih besar daripada penduduk di dalam kota (Pada tahun 1699 jumlah penduduk Batavia 21.911 orang, dan penduduk Ommelanden 49.688 orang. Sedangkan tahun 1759 penduduk Batavia 16.194 orang dan Ommelanden 111.172 orang (Remco Raben, 1996: 309-319). Di wilayah Ommelanden persentase jumlah budak tidak pernah melampaui $30 \%$ dari total jumlah penduduk. Dengan demikian argumen Castles yang menyatakan bahwa budak adalah unsur utama yang membentuk etnis Betawi tidaklah akurat. Jika penduduk Batavia dan Ommelanden digabungkan yang menjadi mayoritas adalah penduduk bebas yang datang dari dalam maupun luar wilayah Nusantara.
Untuk mendapatkan gambaran yang lebih jelas tentang asal-usul orang Betawi ada baiknya kita meninjau secara sekilas komposisi dan proses interaksi penduduk Batavia pada abad ke-17 dan 18 (Bondan, 2007: xii-xiii).

Kota Batavia didirikan oleh Jan Pieterszoon Coen pada tahun 1619 sebagai markas besar bagi kapal-kapal VOC yang melakukan kegiatan perdagangan di Asia. Masalah sumber daya manusia merupakan salah satu masalah utama yang dihadapi Batavia pada masa awal berdirinya. Meski dapat disebut sebagai kota koloni Belanda namun jumlah penduduk asli Eropa selamanya merupakan minoritas di Batavia. Rencana Jan Pieterszoon Coen untuk menjadikan Batavia sebagai kota koloni yang didominasi oleh imigran dari Eropa ditolak oleh Heren XVII (17 direktur VOC yang bermarkas di Belanda). Mereka berkeberatan karena golongan penduduk vrij burgher (orang Eropa bebas) yang dapat berdagang dengan leluasa akan menjadi pesaing dan menimbulkan masalah bagi keberhasilan monopoli dagang yang dijalankan oleh VOC (Bondan, 2007: xiv).

Selain itu jarak yang jauh antara koloni dan negara induk yang hanya dapat ditempuh melalui perjalanan laut yang penuh bahaya merupakan alasan lain yang telah menyebabkan VOC sangat bergantung pada sumber daya manusia di wilayah yang didudukinya. Berbagai suku bangsa yang berasal dari Nusantara dan wilayah lainnya di Asia menjadi penduduk mayoritas Kota Batavia. Kondisi inilah yang menyebabkan penduduk Batavia selama abad ke-17 dan 18 menjadi sangat majemuk, terdiri atas beragam etnis dan secara sosial terbagi dalam suatu hirarki yang mengacu pada kepentingan ekonomi dan politik Belanda di Asia (Bondan, 2007: xiv-xv)..

Pada bagian kedua abad ke-17 situasi keamanan di wilayah sekitar (Ommelan-den) Batavia mulai terjamin setelah VOC berhasil mengikat kontrak perjanjian dengan Mataram pada tahun 
1677, Cirebon 1681, dan Banten 1684. Sejak itu Ommelanden sebagai daerah pendukung bagi Kota Batavia mulai berkembang pesat. Akhir abad ke-17 merupakan periode ekspansi ekonomi Batavia ke wilayah sekitarnya. Kegiatan pertanian, industri gula, pabrik arak, pembuatan batu bata, pembuatan genting dan berbagai kegiatan produksi lainnya tumbuh dengan cepat dan memerlukan tenaga kerja dalam jumlah yang besar. Terbukanya peluang kerja telah menarik kedatangan ribuan orang dari daratan Cina, pedalaman Jawa, dan berbagai penjuru Nusantara. Total penduduk Ommlanden pada tahun 1661 adalah 47.729 orang, jumlah itu bertambah menjadi 82.204 orang pada tahun 1731 dan pada tahun 1781 menjadi 123.003 orang (Gooszen, 2003: 93-116).

Menurut Kanumoyoso (2007: xvixviii) berdasarkan latar belakang sosialnya, penduduk Batavia dan Ommelanden dapat dibagi menjadi empat kategori.

Pertama, para prajurit pribumi dari berbagai daerah di Nusantara yang pernah atau masih bertugas dalam dinas kemiliteran VOC. Rombongan pertama adalah para prajurit Ambon yang tiba di Batavia pada tahun 1656. Pasukan kecil yang berjumlah sekitar 30 orang itu dipimpin oleh Kapitan Tahalele dari Pulau Luhu. Di antara mereka tergabung Jongker dari Manipa yang pada tahun 1658 menggantikan posisi Tahalele sebagai pimpinan pasukan Ambon. Pasukan Ambon diberi sebidang tanah oleh VOC di daerah Marunda. Daerah tersebut sampai sekarang masih dikenal dengan nama Pejongkeran. Kedatangan pasukan Ambon, segera disusul oleh para prajurit dari Makasar, Bugis, dan Bali. Kepada mereka VOC memberi perlakuan yang sama, yaitu menempatkan mereka dalam sebidang tanah untuk membentuk kampung.

Kedua, para budak maupun bekas budak yang telah dibebaskan. Sebutan bagi bekas budak yang telah dibebaskan (membebaskan budak adalah kebiasaan yang lazim dilakukan oleh para pemilik budak di Batavia (lihat Hendrik E. Niemiejer, 2000: 80) dan beragama Kristen adalah Mardijker. Kebanyakan dari mereka berasal dari Pantai Coromandel dan Bengal di India. Mardijker menggunakan bahasa Kreol Portugis untuk berkomunikasi. Sebagian dari mereka bermukim di dalam kota dan sebagian lainnya memilih untuk bertempat tinggal di Ommelanden di daerah sekitar Benteng Rijswijk, di dekat Angke, dan di Tugu. Selain Mardijker para budak lainnya yang dibebaskan berasal dari berbagai etnis yang ada di Indonesia. Pada tahun 1666 VOC berhasil menaklukkan Makasar dan sejak itu banyak budak yang didatangkan dari Sulawesi, Bali, Timor, Buton, Roti ataupun Sumbawa.

Ketiga, para imigran bebas yang tertarik untuk datang ke Batavia. Para imigran bebas dari luar Indonesia mayoritas berasal dari Cina. Para imigran Cina berdatangan karena tertarik oleh perkembangan ekonomi yang pesat di Ommelanden. Orang-orang Tionghoa mengisi berbagai lapangan kerja seperti berdagang, menjadi tukang kayu, perajin, pembuat batu bata, bangunan, jembatan, dan kapal. Selain orang Tionghoa, orang Jawa yang berasal dari Banten maupun daerah kekuasaan Mataram juga berdatangan dalam jumlah yang besar.

Keempat, penduduk yang mendiami Ommelanden juga terdiri atas orang Eropa dan Mestizo. Mestizo adalah orang-orang Kristen yang ayahnya berasal dari Eropa dan beribu Asia. Secara kuantitatif orang Eropa dan Mestizo merupakan penduduk minoritas di Batavia maupun Ommelanden. Meskipun demikian secara sosial mereka menempati kedudukan yang tinggi dan secara ekonomi mereka juga memainkan peranan yang penting (Bondan, 2007: xix).

Proses semakin mencairnya indentitas etnis penduduk Batavia terutama terlihat di daerah Ommelanden. Meskipun pemerin-tah Batavia berusaha menetapkan kebijakan segregasi dengan mendirikan kampung-kampung yang berdasarkan pada 
asal-usul etnis, namun kecenderungan yang terjadi menunjukkan bahwa indentitas etnis tidak banyak memengaruhi pola hubungan masyarakat. Di Ommelanden masyarakat berinteraksi tidak hanya berdasarkan hubungan etnis, namun lebih berdasarkan kepentingan sosial-ekonomi dan kedekatan geografis. Indentitas etnis dalam masyarakat Omme-landen tidak pernah mewujud dengan jelas (Remco, 2000: 94).

Mencairnya indentitas etnis terutama disebabkan oleh: Pertama, banyaknya perkawinan campuran. Anak hasil dari perkawinan campuran pria Eropa dengan perempuan Asia memunculkan kelompok penduduk Mestizo. Sedangkan anak hasil perkawinan campuran orang Tionghoa dengan orang pribumi disebut Peranakan (Tionghoa muslim). Meski demikian, dapat dipastikan bahwa perkawinan campuran lebih banyak lagi terjadi di antara etnis pribumi. Kedua, pengalaman yang dialami secara bersama di dalam dinas kemiliteran VOC. Pasukan pribumi yang terdiri atas berbagai macam etnis di bawah pimpinan Kapitan Jongker dalam ekspedisi ke Banten merupakan salah satu contoh yang dapat dikemukakan. Sekembalinya mereka ke Batavia pada tahun 1683, anggota pasukan tersebut memilih untuk bertempat tinggal di tanah milik Jongker di Marunda. Agaknya solidaritas sebagai sesama pasukan pribumi yang bertempur bersama dalam menghadapi musuh telah melunturkan indentitas etnis dari para anggota pasukan tersebut. Hal yang sama kemungkinan besar juga terjadi pada pasukan-pasukan pribumi lainnya yang dikirim dalam berbagai ekspedisi militer VOC (Bondan, 2007: xxi).

Ketiga, agama juga merupakan salah satu unsur yang menyebabkan melunturnya indentitas etnis. Sebagai contoh adalah keturunan Tionghoa yang menganut agama Islam. Orang Tionghoa yang beragama Islam akan memotong pendek rambutnya dan mengganti nama mereka dengan nama Melayu atau Arab. Orang Tionghoa Islam disebut dengan Peranakan. Indentifikasi yang kuat terhadap suatu agama dapat menegaskan kesamaan indentitas etnis (Remco, 2000: 100). Keempat, institusi perbudakan. Budak yang didatangkan ke Ommelanden berasal dari berbagai macam etnis. Keanekaragaman latar belakang etnis budak terekam dalam catatan statistik budak yang dibebaskan pada tahun 17491750. Dari 304 budak yang dibebaskan pada tahun itu 87 berasal dari Bali, 67 dari berbagai daerah di Sulawesi, 57 dari Asia Selatan, 49 dari Batavia, dan sisanya dari Sumbawa, Jawa, Bima, Timor dan daerahdaerah lainnya di Indonesia (Remco, 2000: 127). Catatan statistik di atas menunjukkan bahwa hampir semua etnis Indonesia yang ada di Batavia terwakili dalam institusi perbudakan.

Dengan memerhatikan beberapa faktor yang dipaparkan di atas, maka pernyataan Castles yang menyatakan bahwa orang Betawi sebagai kategori etnis baru muncul pada abad ke-19 dapat dipertanyakan (Bondan, 2007: xxiii-xxiv).

\section{Pendapat Susan Blackburn}

Di antara kelompok-kelompok etnis di Batavia pada abad ke-19, terjadi transformasi yang menarik. Pada awal abad tersebut, mereka masih dapat dibedakan ke dalam beberapa kelompok, seperti orang Melayu, Bugis, Bali, Sumbawa, Ambon dan lainnya, serta sebuah kategori lain yang mencakup semuanya yaitu budak yang juga datang dari seluruh kepulauan kecuali Jawa. Sepanjang abad tersebut, sisa-sisa kelompok ini dapat ditelusuri di surat kabar Java-Bode, 13/11/1869 dan tanggal 27/12/1879 (Blacburn, 2011: 89).

Berakhirnya perdagangan budak pada tahun 1812 berarti penyerapan budak secara bertahap ke dalam masyarakat Batavia yang lebih luas tidak terhambat oleh para pendatang baru dari Bali, Makasar dan tempat lainnya. Mengingat Batavia pada masa ini adalah ibu kota dari Jawa yang telah ditaklukkan seluruhnya maka tidak ada lagi pelarangan terhadap masuknya orang Sunda maupun Jawa ke 
kota dan menjadi bagian besar dari tenaga kerja kota. Namun sepertinya, kedatangan mereka terjadi secara bertahap sehingga para imigran permanen dapat diserap ke dalam budaya Batavia yang sedang berkembang (Blacburn, 2011: 89).

Populasi orang Indonesia di Batavia meningkat dua kali lipat selama abad ini, dari sekitar 33.000 orang (termasuk semua kelompok etnis dan budak Indonesia) pada 1815, menjadi hampir 78.000 orang pada tahun 1900. Namun, pada tahun 1820-an, percampuran ini menyebarluas sehingga para pengamat tidak dapat lagi membagi komunitas orang Indonesia menjadi kelompok-kelompok etnis tersendiri. Dengan demikian, pada abad ke-19, orang Indonesia yang dilahirkan di Batavia secara umum disebut orang Betawi, sebagai pengakuan bahwa orang Indonesia di kota ini membentuk sebuah kelompok etnis tersendiri (Blacburn, 2011: 90).

Orang Betawi sendiri terbagi-bagi dalam kampung yang tersebar di seluruh kota dan distrik sekitarnya hingga ke pegunungan. Bahkan dalam kampung yang berada dekat pusat kota, cara hidup mereka seperti di pedalaman. Berikut adalah deskripsi sebuah kampung Betawi di Weltevreden pada 1850-an:

Jika kita menyebrangi jembatan Prapatan dari Koningsplein di pagi hari, kita akan melihat Kampung Kwintang yang besar di tepi kali dan sebagian besar penduduknya sedang mandi di Kali Ciliwung. Perahu-perahu yang mengangkut rumput dan sayuran melintas di kali, kuda-kuda mandi di sana bersama manusia, pakaian pun dicuci di sana. Di kampung kita dapat melihat seorang perempuan sedang menumbuk beras, seorang perempuan yang lain sedang menjahit di atas bale-bale di depan pondoknya, ada pula yang sedang menggerus cabe merah menjadi sambel ulek; para lelaki memanjat pohon kelapa untuk mengambil buahnya dan bersiap membawa kelapa-kelapa tersebut ke pasar. Anak-anak kecil berlarian di antara ayam, bebek, angsa, dan anjing (Blackburn, 2011: 92).

Orang Betawi mendapatkan penghasilan dari menjual tanaman tunai, sedikit produksi kerajinan tangan dan memberikan jasa pelayanan seperti menjadi kusir sado atau gerobak lembu, serta pencuci pakaian. Banyak di antara mereka yang menanam sirih dan menjual daunnya sebagai bahan untuk mengunyah sirih. Para lelaki mengumpulkan buah, kayu bakar, rumput (untuk populasi kuda yang semakin banyak) dan sayuran untuk dijual ke kota. Industri rumahan merupakan hal yang biasa. Di sejumlah wilayah, penduduknya menganyam topi dan tikar, dan banyak perempuan mendapatkan penghasilan melalui membatik di rumah. Namun, teknik mengecap yang diperkenalkan pada abad ke-19 telah mengurangi pekerjaan untuk perempuan. Sebelumnya membatik dikerjakan oleh kaum perempuan, kini menekan cap yang berat dianggap sebagai pekerjaan laki-laki, dan karena hal ini lebih baik dilakukan di dalam pabrik-pabrik maka pembuatan batik didominasi oleh pihak-pihak yang memiliki modal yaitu orang Cina (Blackburn, 2011: 93-94).

\section{PENUTUP}

Dari pendapat para pakar yang panjang lebar itu, didapatkan fakta yang didasarkan pada bukti-bukti sejarah, baik itu berupa dokumen maupun artefak arkeologis. Secara garis besar kesemua pakar itu sepakat bahwa etnis Betawi merupakan etnis yang lahir dari pencampuran berbagai macam suku bangsa yang berasal dari wilayah Nusantara bahkan bangsa seperti Portugis, India, Cina, Arab, Belanda, dan sebagainya.

Ketidaksepahaman terletak pada kapan munculnya atau lahirnya etnis Betawi itu dan dari kalangan mana. Sebagian mengatakan etnis Betawi muncul pada abad ke-19, sebagian lagi berpendapat pada abad ke-18, yang lain mengatakan munculnya etnis Betawi pada abad ke-16, bahkan ada yang mengatakan 
munculnya etnis Betawi pada abad ke-20. Kemudian, mengenai kalangan mana yang membentuk etnis Betawi, Lance Castles lebih cenderung menyebutkan kalangan budaklah terutama yang berasal dari Bali sebagai pembentuk utama etnis Betawi. Pada sisi yang lain, Ridwan Saidi menolak keras apa yang dikatakan oleh Lance Castles itu.

Mengenai dua persoalan itu dapatlah dikatakan bahwa terjadinya dua perbedaan itu lebih disebabkan para pakar melakukan interpretasi didasarkan pada dokumen sejarah yang berupa arsip Belanda. Melakukan argumen berdasarkan dokumen itu juga tidak dapat dipegang seratus persen. Dokumen-dokumen itu dibuat dalam suatu kerangka tertentu yang tidak mencerminkan social fact yang sebenarnya.

Dapat dibenarkan apa yang dikemukakan oleh Ridwan Saidi bahwa etnis Betawi tidak muncul secara tiba-tiba. Bukankah suatu kenyataan semua etnis yang ada di Indonesia lahir dari suatu proses yang panjang. Pada konteks inilah, dapat kita terima istilah "proto Betawi" yang diajukan oleh Ridwan Saidi berdasarkan temuan tinggalan arkeologis. Hanya saja, kita tentu saja tidak dapat merangkai kesinambungan dari proto Betawi sampai kepada penduduk Sunda Kalapa, berhubung belum ditemukannya bukti-bukti sejarah. Yang menarik dan sangat penting ialah apa yang dikatakan oleh Ridwan Saidi mengenai penguasaan wilayah Nusa Jawa (tentu termasuk Sunda Kalapa di dalamnya) oleh Sriwijaya. Buah dari penguasaan itu ialah terbentuknya masyarakat Sunda yang tetap berbahasa Kawi dan masyarakat Sunda yang memakai bahasa Melayu sebagai lingua franca. Masyarakat Sunda yang berbahasa Melayu umumnya berada di Sunda Kalapa dan sekitarnya. Bahasa Melayu ini menjadi penting karena di kemudian hari, bahasa ini menjadi salah satu indentitas etnis Betawi.

Sunda Kalapa menjadi pelabuhan terbesar yang dimiliki Kerajaan Sunda, dari kenyataan itu tentu saja masyarakatnya mengalami perkembangan yang pesat. Periode yang juga menentukan adalah dimulainya kekuasaan Islam setelah Sunda Kalapa berhasil direbut oleh Faletehan. Periode ini berhasil mengislam-kan penduduk Sunda Kalapa dan sekitarnya untuk memeluk Islam. Islam pada perkembangan selanjutnya juga menjadi salah satu indentitas etnis Betawi.

Dari tiga periode, yaitu periode Sriwijaya, Kerajaan Sunda, dan Islam sebetulnya sudah dapat dikatakan bahwa dasar-dasar terbentuknya etnis Betawi sudah menjelma. Hanya saja waktu itu, penyebutan istilah Betawi belumlah ada. Orang menyebut penduduk Sunda Kalapa yang sudah berganti nama menjadi Jayakarta dengan istilah "Wong Jakerta/orang Jakarta".

Mengenai istilah "Betawi" mulai muncul pada periode kekuasaan Kolonial bercokol di Jakarta. Di bawah Panji Kolonial, Jakarta berganti nama menjadi Batavia. Masyarakat atau orang Sunda yang wilayahnya dekat dengan Batavia menyebut orang Batavia dengan orang Betawi, hal itu dapat dimengerti karena lidah orang Sunda sulit untuk mengatakan Batavia. Dari penyebutan itulah lambat laun dikenal istilah Betawi untuk menyebut penduduk Batavia. Secara logika penyebutan nama suatu komunitas dimulai oleh masyarakat terlebih dahulu baru kemudian terekam dalam dokumen. Dalam hal Betawi ini, logika itu berlaku. Secara tertulis sebutan orang Betawi pertama kali terdapat dalam dokumen 1644 berupa testamen Nyai Inqua, janda Tuan Tanah Souw Beng Kong, Kapiten Tionghoa pertama di Batavia. Nyai Inqua menyebut seorang pembantu perempuannya adalah orang Betawi.

Berdasarkan sumber sejarah berupa dokumen itu sebenarnya telah dikenal istilah "orang Betawi". Dari bukti itu tentu dapat ditegaskan bahwa istilah etnis Betawi sudah muncul pada abad ke-17. Dengan demikian, dari dokumen itu tentu pendapat para ahli yang mengatakan etnis 
Betawi muncul pada abad ke-18, atau abad ke-19, bahkan abad ke-20 menjadi gugur dengan sendirinya.

Persoalan kapan munculnya istilah orang Betawi/etnis Betawi sudah dapat dipecahkan. Sekarang apakah betul, etnis Betawi berasal dari para budak, khususnya para budak yang berasal dari Bali? Kurang dapat diterima bila para budak dari Bali sebagai unsur utama yang membentuk etnik Betawi. Secara logika, bila para budak dari Bali sebagai unsur utama dalam membentuk etnik Betawi maka tidaklah mungkin etnik Betawi ini berbahasa Melayu dan beragama Islam. Logikanya, bila etnik Betawi unsur utamanya berasal dari para budak asal Bali maka etnik Betawi akan berbahasa Bali dan beragama Hindu. Dari data sejarah kita dapat melihat bahwa para budak dari Bali yang sudah dimerdekakan banyak yang memeluk agama Islam. Itu menunjukkan kepada kita bahwa para budak itu memasuki suatu komunitas yang membuat mereka masuk ke dalam agama Islam. Artinya, komunitas itu adalah suatu komunitas yang lebih besar dan sudah mapan. Hal itu dapat dimengerti karena tidaklah mungkin para budak itu dengan sendirinya berbahasa Melayu dan beragama Islam.

Siapakah komunitas yang lebih besar dan sudah mapan itu? Ia tentulah etnik Betawi. Etnik yang sudah lama mendiami Sunda Kalapa dan sekitarnya. Pada saat Belanda mengambil alih Sunda Kalapa etnik ini tentu tidak musnah. VOC memang menguasai Jayakarta tetapi tidak memusnahkan penduduk Jayakarta dan sekitarnya. Dapatlah dimengerti, apabila penduduk Jayakarta meninggalkan Jayakarta yang sudah berganti nama menjadi Batavia. Tetapi, ke manakah mereka perginya? Tentulah tidak akan jauh dari Batavia, ya masih di seputar Batavia juga mengingat kondisi geografis ketika itu yang masih banyak lahan-lahan kosong. Komunitas etnik Betawi inilah yang menjadi wadah bagi para pendatang baik yang berasal dari wilayah se-Nusantara maupun dari luar Nusantara, seperti
Inggris, Belanda, Portugis, Cina, India, dan lainnya. Komunitas etnik Betawi tentulah yang lebih besar dalam hal jumlah penduduknya bila dibandingkan dengan para pendatang. Bila orang Eropa yang jumlahnya lebih besar tentulah bukan bahasa Melayu yang dipakai atau setidaknya agama Kristenlah yang dianut. Bila orang Cina yang jumlahnya lebih besar tentu bukan bahasa Melayu dan bukan agama Islam yang dianut. Begitu juga bila orang India yang lebih besar jumlahnya tidaklah akan memunculkan bahasa Melayu dan agama Islam.

Dari kenyataan itu, dapat dikatakan bahwa orang Jayakartalah yang menjadi unsur utama pembentuk etnik Betawi. Orang Jayakarta yang dahulunya orang Sunda Kalapa menjadi panci pelebur terbentuknya etnik Betawi. Bahasa Melayu dan agama Islam yang menjadi ciri utama orang Jayakarta menjadi bukti yang tidak bisa dibantah bahwa etnik Betawi dahulunya adalah orang-orang Jayakarta. Begitulah proses terbentuknya etnik Betawi. Komunitas orang Jayakarta yang lebih dominan baik dari segi jumlah dan otoritas menerima berbagai pendatang baru dari berbagai suku bangsa bahkan bangsa membentuk etnik Betawi dengan kebudayaan gado-gadonya di bawah agama Islam. Agama Islam dalam hal ini menjadi perekat berbagai suku bangsa dan bangsa karena pengakuannya akan derajat manusia yang sama. Para budak yang tersia-sia dengan sukarela masuk Islam karena mereka menemukan kembali harkat dan martabatnya sebagai manusia.

\section{DAFTAR SUMBER}

Blackburn, Susan. 2011.

Jakarta: Sejarah 400 Tahun. Penerjemah Gatot Triwira. Jakarta: Masup Jakarta.

Blusse, Leonard. 2004. Persekutuan Aneh: Pemukiman Cina, Wanita Peranakan, dan Belanda di Batavia VOC. Yogyakarta:LKIS. 
Castles, Lance. 2007. Profil Etnik Jakarta. Penerjemah Gatot Triwira. Jakarta: Masup Jakarta.

Dagh-Register, 1674, Batavia. 1902.

De Haan, F. 1935. Oud Batavia. Rev. ed. Vol. I. Bandung: A.C. Mix co.

Departemen van Economicsche Zaken, Nederlandsche Indie. 1935. Volkstelling 1930. Vol. I. Batavia.

Drewes, G.W.J. dalam B. Schrike, ed. 1929. The Effect of Westren Influence on the Native Civilization in the Malay Achipelago. Batavia: G. Kolff \& co.

Goozen, Hans. 2003. Population Census in Batavia 18731892. Leiden: Intercontinenta. No. 25.

Haris, Tawalinuddin. 2007. Kota dan Masyarakat Jakarta: Dari Kota Tradisional ke Kota Kolonial (Abad XVI-XVIII). Jakarta: Wedatama Widya Sastra.

Kanumoyoso, Bondan. 2007. "Pengantar: Perubahan Indentitas Penduduk Jakarta" dalam Castles, Lance. 2007. Profil Etnik Jakarta. Penerjemah Gatot Triwira. Jakarta: Masup Jakarta.

2005.

"The Dynamic of a Hinterland: Ethnic Classification and Kampung Settlements in the Environs of Eighteenth-Century Batavia" dalam Jurnal Pendidikan Sejarah Historia, No. 12, Vol. VI. Bandung: Universitas Pendidikan Indonesia. Desember 2005.

Lekkerkerker, C. 1918.

"De Baliers van Batavia". De Indische Gids.

Melalatoa, M. Junus. 1995.

Betawi dalam Ensiklopedi Suku Bangsa Indonesia. Jilid A-K. Jakarta:
Departemen Pendidikan dan

Kebudayaan.

Milone, Pauline Dublin. 1966.

Queen City of The East; The Metamorphosis of a Colonial Capital, Ph.D. Dissertation. University of California, Berkeley.

Niemiejer, Hendrik E. 2000.

"The Free Asian Christian Community and Poverty in pre-Modern Batavia", dalam Kees Grijns dan Peter J.M. Nas, Jakarta-Batavia: Socio Cultural Essays, Leiden: KITLV Press.

Raffles, T.S. 1830.

History of Java. Edisi Kedua. Volume II. London: Oxford University Press.

Remco Raben. 2007.

"Seputar Batavia: Etnisitas dan Otoritas di Ommelanden, 1650- 1800" dalam Jakarta-Batavia: Esai Sosio-kultural. Penyunting Kees Grijns dan Peter J.M. Nas; Penerjemah Gita Widya Laksmini dan Noor Cholis. Edisi Pertama. Jakarta: Banana, KITLV-Jakarta. 1996.

Batavia and Colombo, The Ethnic and Spatial Order of Two Colonial Cities, 1600-1800, Ph.D. dissertation. Leiden: Leiden University.

Saidi, Ridwan. 2002.

Babad Betawi. Jakarta: Gria Media Prima.

Shahab, Yasmine Zaki. 1994.

The Creation of Ethnic Tradition: the Betawi of Jakarta. Ph.D. dissertation. London: School of Oriental and African Studies.

Taylor, Jean Gelman. 1987. The Social World of Batavia; European and Eurasian in Dutch Asia. Madison: University Wisconsin Press. 